\title{
Institute of Ecology and Bioethics of the Cardinal Stefan Wyszyński University
}

A project was launched at the Institute of Ecology and Bioethics of the CSWU in 2007 with the purpose of developing methods of estimating the condition of holistic education in the field of natural sciences. The research was aimed at developing new systemic solutions that could be implemented in academic teaching syllabi on faculties with specialization in Environmental Protection. The parties involved in preparing the methods of estimation of the condition of holistic education in natural sciences based their efforts primarily on solutions in the field of ecology and knowledge base of other fields of science, including ecological philosophy, geology, hydrology, soil science, or geochemistry.

One of the key stages of this work was to define the research field and the methods of estimation. This stage combines a significant number of substantive issues (a major part whereof has already been discussed earlier). Some of the most significant of these include:

- determining the borderline between the mereological and the holistic level,

- substantive choice of research issues (within the existing fields of science),

- determination of the basic natural unit of reference,

- defining the role of an ecosystem in the holistic approach,

- selection of research areas corresponding to a system with continuous flow of matter and energy,

- choice of research issues accounting for comprehensive knowledge of the natural environment (including William Occam's razor principle [translator's comment: the author probably misspelt the concept of Ockham razor]) within the fields of research,

- determination of range and mutual relationships of selected fields of study,

- method of interpretation of results obtained (choice of proper statistical methods).

One of the key decisions that had to be taken in the course of preparing the present work was to choose the reference system, namely the natural unit of reference. An ecosystem was chosen as the natural unit of reference. An ecosystem seems to be the most appropriate system in view of its role in the 
natural environment. An ecosystem is also a system that can be relatively precisely defined according to energy and matter flow data. This is particularly important in analyzing the processes occurring within environmental systems.

Specification of the base unit is the starting point for studying the role of an ecosystem within a holistic framework and setting out a practical borderline between the mereological level and the holistic level. This is of special importance when an entire conceptual system is being built for defining natural phenomena on a system level. Appropriate choice of such levels, determination of importance ranges and adapting relevant research issues conforming to William Occam's razor principle [translator's note: see previous comment] ${ }^{1}$ is a determining factor for proper definition of these matters within the holistic approach. 9 research areas have been ultimately selected for the discussed paper.

Research was carried out in 2007 among students of the 3 rd year at the Institute of Ecology and Bioethics of the Cardinal Stefan Wyszyński University, specializing in Environmental Protection, on the basis of an e-learning system specifically installed and configured for this purpose. The system was used for preparation of tests using on-line techniques according to recognized international standards.

The interactive e-learning system was used not only for carrying out the research itself but also for basic statistical calculations. Study results in the form of data sheets were then uploaded to Excel where they were processed with mathematical and statistical methods. The results were properly developed for purposes of the implemented programme. The applied method of comparing the results obtained enables far-fetched analysis of knowledge, including fact associating skills, knowledge of concepts or understanding of entire cause-andeffect processes among the interviewed students. All substantive sections that were monitored in combination comprise 105 independent research modules. Each of these modules was monitored independently and then assessed by weight through application of a relevant procedure. The $\mathbb{I}$ solutions used in the present paper were only technical tools for accurate performance of research activities.

Substantive analysis of the entire process of assessment of holistic natural sciences education results has been carried out with the same methodology which should be applied in the process of systematic environmental education, accounting for assumptions arising out of the sustainable development concept.

Specification of new directions for development of holistic environmental education process should be a valuable contribution on the way of systematic actions leading to better recognition of the natural environment and therefore restraining certain adverse processes causing its degradation. Humanities should

Dzıк, J., Dzieje życia na Ziemi, Wprowadzenie do paleobiologii [History of Life on Earth, Introduction to Paleobiology], PWN, Warsaw 2003, p. 523. 
also play an enormous part in this process. ${ }^{2}$ These sciences should primarily focus on the issues of forming pro-ecological awareness and attitudes. This field has been largely underdeveloped in our country. This is related to our political history but also to the lack of radical reform in the methodology of teaching about environmental protection issues. Pro-ecological attitudes can only be developed in those societies which support conscious and systematic education, considering holistic aspects of environmental education. Results obtained in the course of research not only prove the lack of substantive holistic knowledge of the environment but also of pro-ecological awareness as such.

The substantive issues studied did not constitute proportionally adjusted topical areas. Only substantive aspects were taken into consideration while choosing the problems. The ultimate importance and meaning by weight was only established during the phase of final processing of results. Therefore, a comprehensive model could be used in the final analysis, comprising all the 9 studied areas. Specific issues were selected with due consideration of the assumptions for the holistic environmental education methodology. The entire range of environmental problems were accounted for, in accordance with that methodology. The basic systems of holistic character were studied. These systems mean certain phenomena and occurrences frequently exceeding beyond the limits of a single scope of research but located within ecosystems. Obviously, this principle did not apply to global systematic concepts, such as uniformitarianism, catastrophism, geological actualism, Dollo's law, Elton's principle, etc. This part of the project has been designed so that to be able to study the actual level of understanding continuity and causal relations in occurrence of environmental phenomena. Properly compared holistic phenomena within the realm of environmental concepts played a very important part here.

With its accepted methodology, ecology offers the currently most effective way to understand the presence of environmental processes on the holistic level. ${ }^{3}$ Another advantage of ecology is the integration of phenomena occurring on the borderline of abiotic and biotic environments within the range of its methodology.

Research has shown a certain understanding of the existence of mutual relationships for these components of the natural environment. The above also refers to the issue of biocoenoses functioning on the timescale. The problems of their variability, stability or aging effect are being more and more efficiently

2 Уyburski, W., Powstanie i rozwój filozofi ekologicznej [The Origin and Development of Ecological Philosophy], Problemy Ekorozwoju, Lublin 2006, vol. 1, Issue 1, pp. 7-15.

3 Krebs, Ch.J., Ekologia, Eksperymentalna analiza rozmieszczenia i liczebności [Ecology, Experimental Analysis of Layout and Population], PWN Publishing House, Warsaw 1996, p. 734 . 
recognized. This is important mainly in practical terms because it is hard to imagine the process of managing natural environment with such tools as sustainable development concepts to continue in the future without thorough knowledge of such basic phenomena occurring in the environment.

In this part of study, weakest understanding was recorded for processes related to the functioning of food chains and matter and energy circulation. It appears that shortages in this field also affect understanding of numerous phenomena where flows of matter and energy constitute the bases of functioning. For this research part, knowledge ratio has been calculated as 45.4 (of 100 achievable), which is very low and indicates far-ranging mereological approach also to this part of ecological education process. This approach is probably due to the fact that ecological education is still realized in the perspective of biology, which imposes its perspective on the subject and teaching methodology. ${ }^{4}$ A certain surprise is also very poor understanding of phenomena relating to conditions for existence of life, variety of species, or slightly more complex processes such as industrial mutualism. In this case, not only ecology with its methodology should be blamed for these facts. Valid academic teaching syllabi for Environmental Protection faculties hardly cover any issues implementing a closed methodological programme focused on environmental conditions in the perspective of organisms' needs.

The subject closest in range to these issues, namely \oxicology, is not taught at some environmental faculties. Still, this subject covers only a minor section of important issues in this field. The completed study indicates a major lack of historical knowledge in respect of living organisms' changing needs. This is a very important part of environmental education, also in the perspective of understanding such processes as evolutionism, or creationism. Students with university education profile have a natural advantage of knowledge over other environmental education profiles, particularly the engineer profile.

A very important aspect for the analysis of the holistic environmental education process is the understanding of systematic concepts concerning problems with maintaining stability of specific environmental systems. Proper interpretation of processes covered by this part of analysis indicates the ability of systematic forecasting based on knowledge derived from separate fields of basic sciences. Knowledge ratio for this group did not exceed 54.2 (of 100 available), which again indicates rather poor understanding of environmental process issues. Especially low level of awareness is visible in the range of role of environmental parameters and impact of their potential variability on

4 KurnatowsKa, A. (red.), Ekologia i jej zwiazki z różnymi dziedzinami wiedzy [Ecology and its Relationships with Various Fields of Knowledge], PWN Publishing House, Warsaw 1997, p. 290. 
living functions of organisms. Extensive lack of ability to compare functioning parameters of ecosystems is disturbing. This involves stability of ecosystems and the entire range of topics related to impact of anthropological pressure on the natural environment. Within this entire research module, best results were yielded by a test of knowledge of the importance of external energy impact on the advancement of major Earth processes. The situation was significantly worse when it came to recognition of energy and matter circulation within the ecosystems. Compensation mechanisms of environmental parameters by seas and oceans were almost completely unclear, not only with regard to climaterelated issues.

Poorest results were obtained in analysis of the student's knowledge of systematic concepts concerning the issues of human impact on environmental systems. Knowledge ratio for this group was only 34 (of 100 achievable). Within this study group, highest awareness is present in the field of issues related to the role of carbon dioxide in environmental processes. The remaining fields of knowledge in this topical category are recognized only on a superficial level, with very low level of understanding of processes responsible for environmental degradation. There is no cause-and-effect understanding of the impact of human activity on the natural environment. This study group clearly exhibits one-sided mereological approach to the teaching process of environmental protection issues. Separation and some kind of 'methodological discreteness' of basic subjects in education is most evident in this case. There is no process-oriented thinking ability in which the process of analysis would comprise the entire phenomenon, regardless of the existing classification according to science disciplines, which is the major weakness of the contemporary academic teaching system in the field of environmental protection. This weakness shows very strongly in the development and subsequent implementation of the sustainable development concept.

Results of assessment of knowledge of concepts covering the issues related to seas and oceans were significantly better, but also below the assumed minimum threshold. In this study, knowledge ratio obtained by students was 57.3 (of 100 achievable). Analysis of data thus obtained again indicates a convergent tendency existing across the entire research project, consisting in certain knowledge of definitions and abstract concepts, accompanied with extensive inability of carrying out a systematic analysis of processes that may be termed holistic. Inability to analyze the process of continuous occurrence of such ecosystems as oceans and seas on Earth is not only visible from the perspective of physical, chemical or biological processes currently taking place within them, but also with respect to history of their origin. In the historical perspective, it is very interesting why none of the interviewed students was able to mention any source of origin of water on Earth. The question was about water of which seas and oceans later developed. This fact perfectly coincides with one of the hypotheses 
formulated earlier in the paper, certainly evidencing more mereological than holistic approach to the environmental education process.

A very similar knowledge ratio result was obtained in the study of knowledge of systematic concepts relating to extended interpretation of Earth geology. In this case, knowledge ratio was 54.2 (of 100 achievable). The structure of questions asked in this part of study could quite accurately show the level of understanding in the field of processes taking place along the timescale and measured by geological cycles. Glacier processes (which took place during the Pleistocene period) turned out to be least understood by the analyzed students, being not relatively closest to our era but very important for the current functioning of many ecosystems in the country. In this part of the research project, causal relations within the process (the phenomena determining ecosystem-forming components) are clearly not understood. This concerns the bedrock of which soils are later formed.

Despite that fundamentals of Soil Study and Geology have been introduced to the syllabus (at the Environmental Protection specialization), this has not contributed to any significant improvement of knowledge of causal processes in environmental phenomena. This refers for instance to the impact of recent glaciations (within their range of influence) on the functioning of ecosystems formed thereby, or the characteristics of thus produced soil (depending on such factors as, for instance, percentage of silica in bedrock). The above examples are of utmost importance, as they not only prove understanding of existence of continuity within environmental processes, but also directly influence the condition of ecosystems from the perspective of their potential resistance to anthropological pressure processes.

Within the project, a separate research module concerning systematic concepts related to lithosphere has been distinguished. In this study, knowledge ratio was only 43.2 (of 100 achievable). Study results thus confirm the analysis of the previous research module. In terms of the applied methodology of teaching geology, students have the necessary knowledge regarding systematic classification of rocks or their origin. However, they are not able to translate these theoretical basics into applied knowledge. They cannot differentiate the roles of sedimentation rocks from other types of rocks in the construction of land cover surface. The consequences of such ignorance with the interviewed students will certainly become evident in the future when these students begin to take decisions in the process of natural environment management.

Highest knowledge ratio was achieved within the research module concerning systematic concepts related to the atmosphere. In this study, knowledge ratio was nearly satisfactory (almost 70), namely 66.6 (of 100 achievable). Positive results in the category of issues related to processes involving oxygen presence in the atmosphere were a major contribution to the quite satisfactory result achieved in 
this part of study. The ability of systematic thinking in this part of studied issues is probably related to the position of oxygen in education scheme within the existing biology syllabus. Oxygen is discussed in numerous syllabus configurations. Various practical exercises are also carried out. All this probably has a direct impact on the results achieved in this part of study. The condition of monitored knowledge is much worse when it comes to the analysis of oxygen presence in the atmosphere in the historical perspective (this refers primarily to the issues of variability rates of this element's occurrence in the atmosphere, etc.).

The ninth defined research area was the group of systematic concepts related to the pedosphere. The concept of pedosphere was used intentionally because its use is responsible for the specific group of soil formation processes taking place in the surface layer of the Earth crust. In addition, this is one of the most important components of land and water ecosystems. ${ }^{5}$ In the study of this area, knowledge ratio was 53.6 (of 100 achievable). The obtained result indicates poor knowledge of the interviewed students in the field of environmental processes taking place in this part of the environment. Unsatisfactory level of knowledge is clearly visible in this part of study, both on the mereological and holistic level. This situation brings about wrong conclusions drawn by the interviewed students in respect of this area as a consistent environmental system. The consequence of such thinking is a number of wrong conclusions, including that the pedosphere is considered as part of 'renewable' resources of the globe, which is a major substantive error at the very beginning. This results in a number of wrong decisions taken in the process of environmental management with respect to ecosystems where the pedosphere is classified as renewable resources. The consequences of such decisions are visible nowadays, not only in highly industrialized countries but also in those where all natural resources are only means of achieving consecutive political objectives.

Study of this component of the sphere has also proved extensive weakness in understanding the role of the pedosphere as a unique buffer concerning the advancing anthropological pressure process. Despite that the academic syllabus for the interviewed students has been extended with many components constituting important knowledge modules in understanding process phenomena responsible for degradation of the pedosphere, still many factors turn out to be insufficiently recognized. This refers to such issues as the role of granulometric fraction in environmental processes, $\mathrm{pH}$, role of organic matter, adsorption capacity, role of bedrock, etc. Knowledge of these fields is of utmost importance, not only from the perspective of substantive knowledge, but also with respect to potential correct exploitation of the pedosphere for human purposes under the assumption of sustainable development.

5 ZaWadzki, S., ed., Gleboznawstwo [Soil Science], PWRiL Publishing House, Warsaw 1999, p. 559. 
The global knowledge ratio for the entire research project was 50.39 (of 100 achievable). Of course, the study has by no means exhausted all issues that should be included in this type of analysis. Still, the paper provides the necessary input for carrying out the next analysis of scale regarding knowledge and capability of holistic thinking of processes and occurrences present in the natural environment among the analyzed group of students. Even a preliminary analysis of results indicates major shortages of holistic knowledge. The interviewed students still primarily gather their knowledge in mereological cycles, without the necessary holistic knowledge of the natural environment based on these information resources. This knowledge only actually determines the level of skill in proper environmental management and formation, as well as practical implementation of the concept of sustainable development.

The above analysis shows that it is not possible to develop a correct holistic environmental education system on the basis of empirical input only. It must be pointed out here that even the process of directing further development of empirical studies should be carried out with major consideration of ecological philosophers perception of the world. Detachment from this formula will ultimately cause domination of thinking by purely economical categories. This will also affect basic ideological foundations for the assumptions of sustainable development, leading to disharmony between man and nature. A certain dimension of this process will also show in the field of formation of environmental awareness. We should not forget that the entire process of holistic environmental education is carried out with a view to build a constructive and systematic process of holistic education, leading to conscious pro-ecological thinking of the environment and the processes taking place therein, and not only on a consecutive pure analysis. Study on the condition of holistic education should not only bring new solutions in the field of methodology and its practical implementation but also provide the necessary knowledge of building an interdisciplinary system for holistic environmental education.

Regarding proper structuring of the process of holistic understanding of the natural environment, not only the lack of an interdisciplinary methodological platform is important as a field for analyzing processes taking place in the natural environment, but also frequently inconsistent human activity in contact with nature. Long-term exploitation of the natural environment as an inexhaustible reservoir of environmental resources still takes its toll in this respect.

Ecological philosophy should certainly play a larger part in development of methodologies for holistic environmental education than it does at present. It is the only one of all recognized sciences whose scope presently covers the entire conceptual field related to environmental issues. Ecological philosophy as an independent discipline of science, with an established epistemological and methodological status, enables formation of the required attitudes toward 
the natural environment. These attitudes should thereafter provide grounds for development of the entire holistic environmental education process.

\section{LIXERADURA}

Dzıк, J., Dzieje życia na Ziemi, Wprowadzenie do paleobiologii [History of Life on Earth, Introduction to Paleobiology], PWN, Warsaw 2003, p. 523.

KREBS, Ch.J., Ekologia, Eksperymentalna analiza rozmieszczenia i liczebności [Ecology, Experimental Analysis of Layout and Population], PWN Publishing House, Warsaw 1996, p. 734.

Kurnatowska, A. (red.), Ekologia i jej zwiazki z różnymi dziedzinami wiedzy [Ecology and its Relationships with Various Fields of Knowledge], PWN Publishing House, Warsaw 1997, p. 290. 冈yвurski, W., Powstanie i rozwój filozofi ekologicznej [The Origin and Development of Ecological Philosophy], Problemy Ekorozwoju, Lublin 2006, vol. 1, Issue 1, pp. 7-15.

ZaWadzkI, S., ed., Gleboznawstwo [Soil Science], PWRiL Publishing House, Warsaw 1999, p. 559.

\section{SUMMARY}

Preparation of appropriate methodology for teaching about natural resources in accordance with the concept of holistic education is currently becoming one of our major goals. Achievement of these goals is indispensable in the perspective of objectives set within the framework of sustainable development. This article is a general overview of results of studies carried out in 2007 on the condition of holistic environmental education among students of the Institute of Ecology and Bioethics at the Stefan Wyszyński University. These studies have strongly emphasized the issue of distinguishing the mereological approach and the holistic approach to the natural environment with the use of modern methods of estimation.

\section{S区RESZCZENIE}

Przygotowanie odpowiedniej metodyki nauczania o zasobach środowiska przyrodniczego, zgodnych $z$ ideą edukacji holistycznej, staje się jednym $z$ najważniejszych celów przed jakimi obecnie stoimy. Osiągnięcie ich jest niezbędne w świetle zadań, jakie są stawiane w ramach idei zrównoważonego rozwoju. Artykuł stanowi ogólny przegląd wyników badań, jakie zostały preprowadzone w roku 2007 nad stanem holistycznej edukacji środowiskowej wśród studentów Instytutu Ekologii i Bioetyki na UKSW. W badaniach tych, duży nacisk położony został na problematykę oddzielenia podejścia merologicznego od holistycznego do środowiska przyrodniczego, wykorzystujac do tego nowe metody estymacji. 